УДК 044.9:34 (075.8)

DOI https://doi.org/10.32849/2663-5313/2020.9.01

\title{
Анастасія Борисова,
}

аспірант заочної форми навчання

Міжнародного гуманітарного університету

\section{ПОНЯТТЯ ПРИВАТНОПРАВОВИХ ВІДНОСИН У СФЕРІ ІНФОРМАЦЙНИХ КОМУНІКАЦІЙ}

Стаття присвячена дослідженню приватноправових відносин у сфері інформачійних комунікаиій як окремого самостійного виду інформаційних иивільних правовідносин. Встановлена доцільність дослідження й аналізу відносин у сфері інформаційних комунікаиій у їхньому взаємозв'язку з категорією «правовідносини», що зумовлено відсутністю розробленої теорії, сформованих уявлень про правові засоби і методи впливу на інформачійно-комунікативну сферу та зв'язки ї̈ суб'єктів.

Встановлено, що сучасне розуміння інформачійних комунікачій пов'язане з концепиією інформаиійного суспільства, в якому інформачія $і$ знання множаться в єдиному інформаиійному просторі. I саме в інформаційному середовищі виникають інформаційні правовідносини з приводу суспільної комунікаиї̈. Так, суспільні відносини в інформачійній сфері слід розглядати як такі, що врегульовані правовими нормами, і ті, які знаходяться поза таким регулюванням. Спілкуючись чи здійснюючи діяльність в інформачійному просторі щодо майнових і немайнових благ, суб'єкти вступають між собою у правові відносини. Такі соціальні відносини багатьма юристами розглядаються переважно в иивільно-правовому контексті.

У статті зазначається, що правовідносини у сфері інформаційних комунікаиій є самостійним видом інформачійних відносин, що регулюються в тому числі нормами приватного права та мають певні особливості. Так, правовідносини у сфері інформаційних комунікачій характеризуються наявністю «власних» суб'єктів, об'єкта та змістом.

Зазначено, що з огляду на приватноправову природу інформачії як основного складника інформачійних правовідносин взагалі та відносин у сфері інформаційних комунікачій, пов'язаних з інформаційними правами осіб, також надає підстави вважати такі правовідносини приватноправовими у частині регулювання, охорони та захисту прав та інтересів приватних осіб під час здійснення ними своїх суб'єктивних прав ті інтересів у комунікативній сфері.

Різновидами таких відносин слід вважати відносини у сфері е-торгівлі, надання страхових послуг, реалізації та захисту прав інтелектуальної власності, інтернет-маркетингу тощо.

Ключові слова: інформаційні комунікації, цивільні правовідносини, інформаційні правовідносини, інформація, інформаційні права, об'єкт.

Постановка проблеми. 3 активним розвитком сучасних суспільних відносин змінюється і характер взаємозв'язку правових норм та відповідних суспільних відносин, що трансформуються у цій сфері у новий вид правовідносин. Правові відносини у сфері інформаційних комунікацій яскравий приклад цих сучасних тенденцій. Тому у теорії цивільного права не сформовано однозначних поглядів щодо правової природи усіх суспільних відносин, які мають входити до предмета цивільноправового регулювання та які існують у реаліях. Доцільність дослідження й аналізу відносин у сфері інформаційних комунікацій у їхньому взаємозв'язку 3 категорією «правовідносини» зумовлена відсутністю розробленої теорії, сформованих уявлень про правові засоби і методи впливу на інформаційно-комунікативну сферу та зв'язки її суб'єктів.
Аналіз публікацій. Проблемам приватноправового розуміння інформаційних правовідносин та відносин у сфері інформаційних комунікацій присвячено наукові дослідження вітчизняних і зарубіжних авторів: К. Бєлякова, К. Єфремової, А. Кодинець, Є. Литвинова, В. Жукова, В. Калятіна, А. Кодинець, Л. Коваленка, В. Копилова, О. Кохановської, Ю. Носіка, В. Петрова, О. Сергєєва, I. Спасибо-Фатєєвої, М. Рассолова, В. Цимбалюка, О. Яременка й інших учених.

Як зауважують дослідники, незважаючи на значний інтерес науковців до дослідження проблематики інформаційних правовідносин, існують різноманітні підходи та трактування цього поняття. Деякими вченими акцентується увага на існуванні різних підходів до розуміння інформаційних правовідносин: широкого розуміння цих правовідносин (у рамках інформаційної концепції права та наявності інформаційної пов’язаності 
у будь-яких правовідносинах); заперечення існування самостійних інформаційних правовідносин з огляду на те, що вони є лише частиною складних правовідносин [1].

Постановка завдання. Зважаючи на наявні теоретичні прогалини, вважаємо за необхідне поставити такі завдання, як визначення інформаційних правовідносин як загальної категорії правовідносин в інформаційному суспільстві, встановлення правової природи та визначення правовідносин у сфері інформаційних комунікацій як самостійного виду інформаційних правовідносин, визначення основних особливостей приватноправового регулювання відносин у сфері інформаційних комунікацій тощо.

Метою статті $\epsilon$ встановлення правової природи та визначення правовідносин у сфері інформаційних комунікацій.

Виклад основного матеріалу. Сучасне розуміння інформаційних комунікацій пов'язане 3 концепцією інформаційного суспільства, в якому інформація і знання множаться в єдиному інформаційному просторі. Головними продуктами, що виробляе інформаційне суспільство, стають інформація і знання. Впровадження сучасних інформаційних технологій в усі сфери людського життя кардинально трансформує суспільство. Особливо яскраво на тлі бурхливого прогресу цих технологій виділяється всесвітня глобальна мережа Інтернет, яка змінює умови формування особистості у сфері інформаційних комунікацій.

Досліджуючи правові відносини у сфері інформаційних комунікацій, насамперед потрібно визначити загальні властивості правовідносин з урахуванням їхнього існування у контексті дихотомії «приватне право - публічне право». Складність визначення правової природи правовідносин у сфері інформаційних комунікацій зумовлюється відсутністю легального визначення категорій «інформаційні правовідносини» та «інформаційні комунікації», різним за змістом використанням у національному законодавстві та різними думками у юридичній науковій літературі.

Як зазначає О. В. Кохановська, у вітчизняній доктрині права натепер сформувалося декілька теорій щодо поняття, змісту і місця інформаційних відносин у системі права і системі законодавства України. Їх становлення відбувалося починаючи із середини XX століття і продовжується нині. Перш за все, вражає різноманітністю спектр поглядів на інформацію як об'єкт правовідносин, особливості суб'єктного складу інформацій- них правовідносин, дискусії щодо предмета і методу, принципів цих відносин [2].

Українська дослідниця Л. П. Коваленко, дотримуючись інформаційної концепції права, визначає інформаційні відносини як відокремлену, однорідну групу суспільних відносин, що виникають під час обігу інформації в інформаційній сфері в результаті здійснення інформаційних процесів у порядку реалізації кожним інформаційних прав і свобод, а також у порядку виконання обов'язків органами виконавчої влади й місцевого самоврядування щодо забезпечення гарантій інформаційних прав і свобод [3]. Аналогічну думку висловлює і відомий фахівець в галузі інформаційного права В. А. Копилов, який інформаційні відносини характеризує як комплекс суспільних відносин, що виникають під час реалізації інформаційних процесів, тобто під час створення, отримання, обробки, накопичення, зберігання, пошуку, розповсюдження та споживання інформації, а також процесів створення і застосування інформаційних систем [4].

Вважаємо, що правовідносини у сфері інформаційних комунікацій є самостійним видом інформаційних відносин, що регулюються в тому числі нормами приватного права та мають певні особливості. Так, правовідносини у сфері інформаційних комунікацій характеризуються наявністю «власних» суб'єктів, об'єкту та змістом.

Інформаційні правовідносини, як вважає О. В. Кохановська, як особисті немайнові, так і майнові, мають приватноправову природу і не потребують штучного обмеження i безмежного контролю, а права на повагу до інформації як особистого немайнового блага фізичної особи слід дотримуватися ще до моменту народження людини, навіть до того, як вона набуде статусу суб'єкта права. Фактично право на повагу до інформації, яка є сутністю людини разом із матерією, в якій вона уособлюється, яку несуть, зокрема гени, слід визначити у законодавстві так само як право на повагу до життя зачатої дитини, тобто 3 моменту зачаття [5].

Зі змісту статті 3 Закону України «Про інформацію» випливає, що інформаційними $є$ правовідносини, які виникають у всіх сферах життя і діяльності суспільства і держави під час одержання, використання, поширення та зберігання інформації. Це визначення $€$ загальним, яке не встановлює особливості цієї категорії серед інших правовідносин.

В основу змісту визначення інформаційних відносин у ст. 3 Закону України «Про інформацію» покладено принцип ототожнення інформаційних відносин з інформаційною діяльністю, оскільки одержання, 
використання, поширення та зберігання інформації є основними видами інформаційної діяльності згідно 3 положеннями ст. 14 цього закону. Але ця норма не має вказівки на такі види інформаційної діяльності, як обробка та захист інформації, що також становить зміст інформаційної діяльності.

Таким чином, можна зазначити, що інформаційні правовідносини - це суспільні відносини, врегульовані нормами приватного та публічного права, між самостійними суб'єктами щодо здійснення інформаційної діяльності з одержання, використання, обробки, поширення, зберігання та захисту інформації та інформаційних прав. Інформаційні правовідносини $є$ міжгалузевим інститутом, норми якого мають як публічний (конституційний, адміністративний характер), так і приватний (цивільний) характер.

Також, як зазначає О. Кохановська, у спектрі теорій, які висуваються представниками правової науки, обгрунтовуються також підходи до інформаційних відносин як галузевих і як інституту комплексного галузевого законодавства, але значних заперечень з точки зору аргументів, які ними висуваються, з боку представників двох основних теорій вони не викликають, а слугують лише доповненням [5].

Інформаційні правовідносини виникають в особливій сфері. Як зазначають дослідники, однією з визначальних рис сучасності $€$ високий попит соціальних суб'єктів на інформацію та продукти з інтелектуальноінформаційною природою. Як наслідок, поряд із традиційними сферами суспільної життєдіяльності, дедалі більшого значення набуває сфера інформаційна, що актуалізує наукові дослідження в цьому напрямі [6].

I саме в інформаційному середовищі виникають інформаційні правовідносини з приводу суспільної комунікації. Так, суспільні відносини в інформаційній сфері слід розглядати як такі, що врегульовані правовими нормами, i ті, які знаходяться поза таким регулюванням. Обгрунтованим є узагальнююче трактування суспільних відносин як структурної сукупності конкретно історичних соціальних зв'язків, залежностей та обмежень, які виникають у процесі і результаті суспільно значимої предметної діяльності і мають властивість постійно повторюватися [7].

Дослідники вважають (і ми також підтримуємо цю думку), що інформаційні відносини як суспільне явище є особливою групою відносин, які мають місце в інтегративній інформаційній сфері в процесі здійснення діяльності, пов'язаної з інформацією.

3 правової позиції їх можна трактувати як особливу групу відносин, які виникають, розвиваються і припиняють свою дію в процесі здійснення різних видів соціальної діяльності щодо створення, збирання, одержання, зберігання, використання, поширення, охорони та захисту інформації, яка регулюється нормами інформаційного права та інших галузей системи національного законодавства, а також міжнародними нормами [6].

Крім того, з огляду на приватноправову природу інформації як основного складника інформаційних правовідносин взагалі та відносин у сфері інформаційних комунікацій, пов'язаних з інформаційними правами осіб, також надає підстави вважати такі правовідносини приватноправовими у частині регулювання, охорони та захисту прав та інтересів приватних осіб під час здійснення ними своїх суб'єктивних прав ті інтересів у комунікативній сфері.

Фахівці в галузі інформаційного права підкреслюють, що суспільні відносини в інформаційній сфері потребують правового регулювання тоді, коли їх предметом виступають суспільно значимі процеси, пов'язані 3 обігом та використанням інформації, a суб'єкти правовідносин мають взаємні права і обов'язки, гарантовані державою [8].

Такі відносини виникають 3 приводу комунікації суб'єктів з використанням сучасних інформаційних технологій, засобів стільникового зв'язку, супутникового телебачення, «електронних коштів», всесвітньої інформаційної мережі Інтернет та інших сучасних засобів. Такі відносини отримали також «сучасне» визначення як віртуальні комунікації або мережеві комунікації.

Але, як зазначають вчені, комунікативний процес не зводиться лише до обміну інформацією (iї передачі та сприйняття), а й передбачає ще трансформацію цієї інформації в соціально значущі індивідуальні, групові чи масові дії. Механізм такої трансформації забезпечується переважно мовною діяльністю людей, бо саме за її допомогою транслюються в соціальному просторі і часі норми та правила спілкування як норми і правила соціальних дій.

Складна юридична природа суспільних відносин в інформаційній сфері передбачає необхідність їх типологізації, тобто виділення із загального масиву цих відносин окремих складників, об'єднаних типовими характеристиками. На цій основі дослідники виокремлюють інформаційні правові відносини, інформаційно-інфраструктурні, інформаційно-процедурні та інформаційно-процесуальні правові відносини [9]. Але не всі 3 цих видів мають приватноправову природу правового регулювання.

Спілкуючись чи здійснюючи діяльність в інформаційному просторі щодо майнових 
і немайнових благ, суб'єкти вступають між собою в правові відносини. Такі соціальні відносини багатьма юристами розглядаються переважно в цивільно-правовому контексті [10].

Як зазначає А. Кодинець, інформаційні цивільні відносини неоднорідні за змістом. Значна їх кількість виникає у зв'язку з реалізацією інформаційних прав особи з набуття та використання інформації. Це, передусім, абсолютні інформаційні відносини, в яких праву однієї особи на інформацію протистоїть обов'язок усіх інших членів суспільства не порушувати інформаційні права суб'єкта. Такі відносини виникають, зокрема, під час використання інформації, її обробки чи збереження. За цих відносин уповноважений суб'єкт має можливість вимагати захисту своїх інформаційних прав від будь-якої особи, яка їх порушить. Значну питому вагу у сфері інформаційних відносин становлять також правові відносини між конкретними особами, в межах яких задоволення інтересів однієї особи здійснюється за рахунок виконання свого обов'язку іншою стороною правовідносин [11].

Правовідносини у сфері інформаційних комунікацій є самостійним видом інформаційних цивільних відносин. Особливостями таких правовідносин, на наш погляд, є такі:

- такі правовідносини зумовлюються об'єктивними економічними чинниками, заснованими на різних формах власності, в тому числі і на інформацію, інформаційні технології, і являють собою суспільні відносини юридично самостійних осіб, у тому числі фізичних та юридичних осіб, інших суб'єктів права;

- це відносини осіб, державних органів, засобів масової інформації, передбачені і врегульовані нормами цивільного права, які закріплюють право на інформацію, захист інформаційних прав та інтересів;

- такі відносини є засобом вирішення завдань у сфері формування інформаційноправового простору країн, захисту прав людини на інформацію. Такі правовідносини виникають щодо реалізації інформаційних прав особи, і зміст їх полягає у здійсненні певних дій з метою отримання різних видів інформації, захисту прав на інформацію, реалізації прав інтелектуальної власності у сфері інформаційної комунікації;

- правовідносини у сфері інформаційних комунікацій виникають на підставі вольових дій суб'єктів права, спрямованих саме на те, щоб результатом таких дій було виникнення певних правовідносин або досягнення певної правової мети. Так, до таких підстав належать юридичні факти у вигляді юридичних дій (правомочні або неправомочні) - правочини або порушення інформаційних прав та інтересів осіб у сфері інформаційних комунікацій;

- також правовідносини у сфері інформаційних комунікацій мають певний склад, який зумовлюється приватноправовою природою правового регулювання цих правовідносин. Особливості стосуються кола суб'єктів, учасників таких правовідносин, поняття та видів об'єктів та змісту правовідносин у сфері інформаційних комунікацій.

- особливістю відносин у сфері інформаційних комунікацій також є їх опосередкованість та необмежений простір застосування. Тому слід зазначити, що основна частина правовідносин у сфері інформаційних комунікацій виникають, існують у межах або за допомогою мережі Інтернет. Інтернет-простір є засобом формування специфічного різновиду комунікацій (Інтернет-комунікації), які, між іншим, можуть бути проінтерпретовані таким же чином [12]

Слід зазначити, що такий перелік особливостей правовідносин у сфері інформаційних комунікацій не є остаточним. У процесі здійснення таких правовідносин та розвитку технологій у сфері інформаційних комунікацій можуть формуватися інші особливості, які розкривають суть правовідносин у сфері інформаційних комунікацій.

\section{Висновки}

3 огляду на ці особливості, а також на те, що ці правовідносини є окремим самостійним видом інформаційних відносин, які $є$ більш загальною категорією, та наявність у правовому регулюванні цих відносин елементів приватного та публічного права, вважаємо, що правовідносини у сфері інформаційних комунікацій мають змішану правову природу, але є самостійним видом цивільноправових відносин у сфері інформаційних комунікацій.

\section{Список використаних джерел:}

1. Коваленко Л.П. Теоретичні проблеми розвитку інформаційного права України. Харків: Право, 2012. С. 98.

2. Кохановська О.В. Приватно правове розуміння інформаційних відносин. URL: https://core.ac.uk/download/pdf/156902799.pdf (дата звернення: 18.08.2020).

3. Коваленко Л. П. Інформаційне право України: проблеми становлення та розвитку : автореф. дис. ... докт. юрид. наук: 12.00.07. Харків, 2014. 37 с.

4. Копылов В. А. Информационное право : учебник. Москва : Юрист, 2002. С. 68

5. Кохановська О. Основні теорії у сфері інформаційних правовідносин: концепція інформаційних прав як приватноправового інституту і теорія інформаційного права як галузі права 
у сучасній правовій доктрині України. Приватне право. 2013. C. 187. URL: //irbis-nbuv.gov.ua (дата звернення: 18.08.2020).

6. Яременко О. I. Інформаційна сфера як соціально-правове явище: проблеми наукової ідентифікації та регулювання. Інформація і право. 2017. № 1. C. 5-13. URL: http://nbuv.gov.ua/UJRN/ Infpr 2017 1 3. (дата звернення: 18.08.2020).

7. Ткаченко Ю.Г. Методологические вопросы теории правоотношений. Москва : Юрид. лит., 1980. C. 84

8. Фурашев В.М., Петряєв С.Ю., Поперечнюк В.М. Систематизація і розвиток теоретичних основ трансформації інформаційних відносин на шляху до кіберцивілізації : наук. доп. Київ : ФСП НТУУ «КПІ», 2016. С. 11.

9. Яременко O.I. Теоретико-методологічні підходи до юридичної природи інформаційних відносин та їх типологізація. Інформація $і$ право. 2016. № 4. С. 13-21.

10.Беляков К. І. Понятійні та методологічні основи регулювання нових типів інформаційних відносин: «віртуальні правовідносини». Lex Portus. 2016. № 2. С. 47-63. URL http://nbuv.gov.ua/UJRN/LP_2016_2_7. (дата звернення: 18.08.2020).

11. Кодинець А. О. Засади цивільно-правового регулювання інформаційних зобов'язань: проблеми теорії та практики. Право України. 2018. № 1. C. 72-80. URL: http://nbuv.gov.ua/ UJRN/prukr_2018_1_8. C. 74. (дата звернення: 18.08.2020).

12. Сидоров М.В. Табаков Д.В. Інтернет як засіб соціальної комунікації та соціального впливу. Політичний менеджмент. 2008. № 4 (31). C. $119-125$.

Anastasiia Borysova. The concept of private legal relations in the field of information communications

The article is devoted to the study of private legal relations in the field of information communications as a separate independent type of information civil relations. The expediency of research and analysis of relations in the field of information communications in their relationship with the category of "legal relations", due to the lack of developed theory, formed ideas about legal means and methods of influencing the information and communication sphere and relations of its subjects.

It is established that the modern understanding of information communications is connected with the concept of information society in which information and knowledge multiply in a single information space. And it is in the information environment that information legal relations about public communication arise. Thus, public relations in the information sphere should be considered as those that are regulated by legal norms, and those that are outside such regulation. By communicating or carrying out activities in the information space on property and non-property goods, the subjects enter into legal relations with each other. Such social relations are considered by many lawyers mainly in the civil law context.

The article notes that legal relations in the field of information communications are an independent type of information relations, which are regulated, inter alia, by the rules of private law and have certain features. Thus, legal relations in the field of information communications are characterized by the presence of "own" subjects, object and content.

It is noted that given the private law nature of information as the main component of information relations in general and relations in the field of information communications related to information rights of individuals, also provides grounds to consider such relations as private law in terms of regulation, protection and protection of rights and interests of individuals in the exercise of their subjective rights and interests in the communicative sphere.

Will consider the types of such relations, relations in the field of e-commerce, insurance services, implementation and protection of intellectual property rights, Internet marketing and more.

Key words: information communications, civil legal relations, information legal relations, information, information rights, object. 